\title{
KEY SKILLS FOR ALL? THE KEY SKILLS QUALIFICATION AND CURRICULUM 2000
}

\author{
Ann Hodgson and Ken Spours \\ Institute of Education, University of London
}

\begin{abstract}
It is widely recognised that the Key Skills Qualification, an important component of the Curriculum 2000 advanced level curriculum reforms has experienced extensive problems during its first full year of implementation. This much is not in dispute. What is being keenly debated, however, are the ways in which this experience should be analysed and what lessons should be drawn. Is it a case of understandable 'teething problems' which will be overcome as the qualification 'beds in' or are there deeper and more fundamental problems of the purpose and design of the Key Skills Qualification for advanced level students?
\end{abstract}

In order to address these questions, this article examines the Key Skills Qualification within its historical and policy context as well as bringing together a range of quantitative and qualitative evidence gathered as part of an Institute of Education (IOE)/Nuffield Foundation Research Project. The research suggests that while there is support for the concept of key skills, the Qualification has been met with considerable student and professional resistance due to its narrow skills focus and assessment regime within the context of increased study programmes at advanced level. We conclude that the Government's aim of 'key skills for all' at advanced level is unlikely to be achieved unless it takes a fundamentally different approach to policy in this area. 


\section{THE ENGLISH APPROACH TO CORE/KEY SKILLS: DEBATES AND DEVELOPMENTS}

Since the late 1970s and the 'Great Debate' about the role and purpose of education, key/core skills have had an almost totemic significance for the English post-16 education and training system. Debates have raged over exactly what the key/core skills are or ought to be, how they should be developed, whether they can be transferred from one context to another and how they should be recognised and accredited. However, the belief that their absence in young people constitutes one of the major weaknesses of our education and training system and that their development would ensure a more highly skilled and competent workforce has continued for over 25 years. This section of the article provides a brief historical background to the development of the current Key Skills Qualification in order to explain why it has emerged in its present form as part of the Curriculum 2000 reforms and why it might be experiencing difficulties in this context.

\section{Core/key skills - debates and developments in the English context in the 1980s and $1990 s$}

While debates about the role of the education system in relation to the economy became highly public at the end of the 1970s with Prime Minister James Callaghan's speech at Ruskin College (Callaghan 1976), as Green (1997) points out, the lack of a strong approach to technical and vocational education in this country had been seen as a problem throughout the twentieth century. In comparison with other European countries, Green argues, technical and vocational education in the UK tended to be narrow and to lack an element of general education. At the same time, general education, pre- and post-16, consisted largely of the study of academic disciplines with little attention paid to the application of skills and knowledge. Pressures for building more general education into technical and vocational education and more applied skills into academic education, in order to make both more responsive to the demands of the economy, thus began to grow towards the end of the 1970s and early 1980s. These demands became more pressing as youth unemployment rates rose and the education and training system was increasingly criticised for failing to provide the workforce the UK needed to compete in the world economy. It was at 
this point that the first steps towards the process of developing core/key skills were taken and, since addressing the needs of unemployed or lower-achieving young people was the most pressing demand, it is here that development took place first.

\section{The first steps towards core/key skill development - the origins of remedialism}

During the early 1980s a series of pre-vocational and vocational qualifications courses and programmes, such as Unified Vocational Preparation (UVP), the Youth Training Scheme (YTS) and the Certificate of Pre-Vocational Education (CPVE) were developed which all contained the type of core/key skills it was felt young people needed to make them more employable. Following an influential report by the Further Education Unit (FEU), A Basis for Choice (1979), core/key skills were developed in each of these awards and programmes.

What was also common to all these developments was the fact that they were largely targeted at lower-achieving young people. They were for those who did not have sufficient qualifications, skills or experience to enter the labour market directly or to continue on to academic postcompulsory study. In this first stage of their development, therefore, core/key skills were associated with an idea of remedial education, basic skill development and courses for lower achieving students to develop flexible skills to cope with a context of high unemployment.

\section{Key skills for all - a potential breakthrough at the end of the $1980 \mathrm{~s}$}

From the mid 1980s to the beginning of the 1990s, however, there were a number of policy moves towards a more common approach to core/key skills involving students with a range of abilities and on both academic and vocational programmes. The Extension Phase of the Technical and Vocational Education Initiative (TVEI) was introduced into all schools and colleges which made the development of certain types of curricular experiences and processes focusing on core/key skill acquisition (e.g. work-related learning, careers education and guidance, IT and recording of achievement) a requirement for schools and colleges seeking funding from this initiative. Her Majesty's Inspectorate (HMI) published a paper in support of core skills in 1989 (HMI 1989). John McGregor, Secretary of State in 1989, taking his cue from his

predecessor, Kenneth Baker, urged the curriculum and qualifications regulatory and advisory bodies - The Secondary Examinations and Assessment Council (SEAC), The National Council for Vocational Qualifications (NCVQ), The National Curriculum Council (NCC), The Further Education Unit (FEU) and the Training Agency - to report on which core skills could be 
incorporated into programmes of study for 16-19 year olds following Advanced Level (A Level), Advanced Supplementary Level and other courses (SEAC 1991). The Confederation of British Industry (CBI) published its influential document Towards a Skill Revolution (CBI 1989), which recommended the development of core skills within all types of vocational education and training and building skills as well as knowledge acquisition into the national curriculum and, at the end of the decade, the NCC Report on Core Skills in 16-19 programmes came out (NCC 1990).

While there was still no absolute agreement about which specific core/key skills should be developed and supported in programmes for 16-19 year olds, in the majority of reports there was a discussion of communications, problem solving, personal skills, numeracy, IT and, in many cases, a modern foreign language. More importantly, the idea that there were a number of generic skills which all post-16 students needed to develop, regardless of their ability, qualifications and educational or training context, was manifested for the first time in concrete policy terms at the end of the 1980s.

Part of the political support for core/key skills at this time was fuelled by international studies on skills and qualifications acquisition in which the UK appeared to be doing badly in comparison with other developed countries (e.g. OECD 1985, DES 1985). There was a commonly held assumption, supported by human capital theory, that raising the level of skills and qualifications within the population would contribute directly to increased productivity and economic competitiveness (e.g. CBI 1989, DE 1988, 1989). In addition, the arguments about the narrowness of the curriculum for 16-19 year olds in relation to their counterparts in Europe continued to be used as part of the rationale for supporting core/key skills (Green 1997).

Although the political argument around the necessity of all post-16 students developing core/key skills was largely won by the beginning of the 1990s, the technical issues surrounding their development within all post-16 qualifications were far from being resolved (SEAC 1991). These practical issues, together with the traditional fear of diluting A Levels ensured that, despite the rhetorical commitment to the development of core/key skills in all post-16 programmes, in fact the main developments in this area continued to be taken forward in the vocational track throughout the 1990s.

\section{Retreat from core skills and entitlement - GNVQs and Key Skills}


We have argued elsewhere (Hodgson and Spours 1997) that the 1991 White Paper, Education and Training for the 21st Century (DfE/ED/WO 1991) marked a policy move away from some of the arguments for a common entitlement for 14-19 year olds which were around at the end of the 1980s. Against a background of rising levels of full-time participation in post-16 education, the White Paper set the agenda for a much more sharply delineated triple-track post-16 qualifications system through the introduction of the General National Vocational Qualifications (GNVQs).

The fact that it was exclusively in GNVQs that core/key skills became a requirement meant that once again in the early 1990s core/key skills became associated with vocational education rather than with the more prestigious academic track. This legacy, we will suggest later in this paper, has had a profound effect on how the current Key Skills Qualification is viewed by students, teachers and higher education providers.

It might be wrong, however, to see the national policy drive for qualifications distinctiveness as the only reason for government back-pedalling on the core skills entitlement agenda at the beginning of the 1990s. Numerous papers by NCVQ, SEAC and the Schools Curriculum and Assessment Authority (SCAA) throughout the 1990s bear witness to the significant technical and practical implementation difficulties of introducing core/key skills into A Levels and National Vocational Qualifications (NVQs) or into post-16 programmes in general (e.g. SEAC 1991, Oates 1992, 1996). Indeed these early concerns about the practicalities of introducing and assessing core/key skills within all post-16 programmes were borne out by the experience of GNVQ programmes, as several school and college inspection reports testify (e.g. FEFC 1994, HMI 1996). The government's cautious approach to core/key skills at this time may therefore also have had a very pedestrian underlying rationale - the simple difficulty of realising the concept of core/key skills for all in practice. Again, we will return to this issue when we examine the policy of 'key skills for all' which became part of the New Labour Administration's educational agenda in 1997.

\section{The professional consensus and the debate about key skills - a search for breadth, skill development and remediation}

While the national policy drive to develop core skills more broadly as an entitlement within all post-16 qualifications appeared to run out of steam during the early 1990s and was replaced by their development within GNVQs, there was still strong support for their development within the 
16-19 curriculum from employers (e.g. Institute of Directors 1992) and particularly from education professionals. Numerous policy documents from academics, researchers and teacher professional associations put forward proposals for reforms to the 16-19 or 14-19 curriculum which included a common entitlement to core/key skills (e.g. Finegold et al. 1990, APVIC 1991, Royal Society 1991, SHA 1993). What united these documents and proposals was a critique of the narrow post-16 qualifications currently on offer (particularly A levels) and a desire to develop a broader, more flexible curriculum for 16-19 year olds or, in some cases, 14-19 year olds, which focused on application of knowledge and skills as well as on academic theory. The argument for an entitlement to develop core/key skills was seen as part of this broad preparation for further study and adult life as well as a way of ensuring that all young people gained the basic skills needed for employment. Key skills were also seen as a way of linking separate qualifications tracks (Raffe et al. 1998)

\section{Dearing and key skills - setting the agenda for the late 1990s and Curriculum 2000}

During the mid-1990s, Gillian Shephard, the Conservative Secretary of State for Education and Employment at the time, recognising that there were still substantial problems with the post-16 qualifications that had developed out of the 1991 White Paper, set in train a significant review agenda. This resulted in three major reports which all had an impact on the development of core/key skills - Review of 100 NVQs and Scottish Vocational Qualifications (SVQs) (Beaumont 1995); The GNVQ Assessment Review (Capey 1996) and the Review of Qualifications for 16-19 Year Olds (Dearing 1996). It was the third of these, however, that had the greatest influence on the way that core/key skills developed in the late 1990s, effectively setting the agenda in this area for New Labour's Qualifying for Success (DfEE/DENI/WO 1997) proposals and resulting in the development of a free-standing Key Skills Qualification in Communication, Application of Number and IT as part of the Curriculum 2000 reforms introduced in September 2000.

In Section 7 of his Report, entitled Improving skills for work and lifetime learning, Lord Dearing, Chair of the National Review of Qualifications for 16-19 Year Olds, stresses the need to improve standards in the skills of communication and application of number which his evidence suggests have not been adequately developed within the national curriculum. While recognising the significance that end-users of education, and in particular employers, attach to these particular two skills, he also argues for the foregrounding of IT as a skill that will become increasingly important in the future. These three skills he then refers to as 'the key skills for all our young 
people' (Dearing 1996: 46). Other skills which had previously been discussed as part of the core/key skills debate - team-working, inter-personal skills, problem solving and managing one's own learning - are referred to as "wider skills". The discussion which follows in the Report is very much related to a basic skills approach to key skills and echoes some of the much earlier discussions about the problems of low standards in English and mathematics in this country (Bullock 1975, Cockcroft 1981).

Here already we can see two related lines of argument which were to prove so influential in the new Labour Government's thinking in its consultation document on reforms to 16-19 qualifications Qualifying for Success (DfEE/DENI/WO 1997) - the division between different types of core/key skills - the three main key skills and the wider key skills - and the confusion between the three main key skills and basic skill acquisition.

A third important strand of influence on the Government's policy in this area was undoubtedly Lord Dearing's suggestion of developing a free-standing qualification in the key skills of communication, application of number and IT, but not making it mandatory for the award of advanced level qualifications. Rather, he suggests, and the Government took this line in Qualifying for Success, that key skills should be built into A Level subject cores and syllabuses and that 'all schools, colleges and training bodies.....should provide opportunities for young people to develop these skills and to have them assessed' (DfEE 1997: 54).

The two major differences between the Dearing approach to the Key Skills Qualification and the approach taken by the Labour Government in Qualifying for Success is that Lord Dearing recommended that the Key Skills Qualification should be developed as a new Advanced Subsidiary (AS) qualification and that it should be a requirement at Level 3 for gaining the Advanced Level National Certificate or Diploma he also proposed in his Report. Neither of these recommendations, as we shall see below, was taken forward in the final Curriculum 2000 qualifications reform process. The decision not to proceed with these particular recommendations could be seen as a movement away from real commitment to 'key skills for all'. In particular, the decision not to include any form of overarching certificate or diploma as part of the Curriculum 2000 reforms has, arguably, removed one of the most effective ways of securing learner, teacher and higher education commitment to key skills at advanced level. 


\section{The purpose and design of the Key Skills Qualification within the context of Curriculum 2000}

The Key Skills Qualification that emerged from the Qualifying for Success agenda and is being implemented as part of Curriculum 2000 assesses achievement in the three main key skills of Communication, Application of Number and Information Technology. The so-called Wider Key Skills - Problem-Solving, Working With Others and Improving Own Learning and Performance do not form part of the Key Skills Qualification, but can be accredited separately through individual Wider Key Skill Units. The units of the Key Skills Qualification can be achieved at different levels. Each unit is assessed by providing portfolio-based evidence and taking external tests. Much of this evidence is intended to be gathered from learners' main programmes of study and all Advanced Subsidiary (AS) and Advanced Certificate of Vocational Education (AVCE) specifications 'signpost' where there are opportunities to assess the six key skills (QCA 1999).

It is intended that the Key Skills Qualification should be offered to all 16-19 year olds although it is not mandatory for learners to take it or for schools and colleges to offer it. However, the Government has put substantial resources into a Key Skills Support Programme delivered by the Learning and Skills Development Agency (LSDA) and offered to all schools and colleges free of charge. It has also provided dedicated funding for general further education and sixth form colleges to offer the Key Skills Qualification as part of a Curriculum 2000 entitlement programme for 16-19 year olds.

This approach to core/key skills undoubtedly constitutes a break with the past. It is an attempt to associate key skills with all types of programmes for 16-19 year olds rather than exclusively with vocational qualifications. While key skills are signposted within AVCEs, successfully demonstrating competence in the three main key skills is not a requirement of gaining the award as it was with GNVQ. There is also an attempt to indicate that curriculum breadth at advanced level can be provided through the acquisition of skills as well as through the more traditional means of taking additional academic subjects. These two approaches to core/key skills development might be seen as broadly progressive and even innovative. However, Dearing's recommendation to focus on the three key skills closely associated with employability marked a critical moment and, in our view, a mistake. In order to deliver 'key skills for all' at advanced 
level, Dearing could have broadened the range of key skills to encompass those needed for progression to higher levels of study so that key skills could appeal to a wide range of students, most of whom would be aiming for progression to higher education. Instead, the focus was narrowed.

The Labour Government adopted Dearing's approach but with its own policy emphasis on national standards and inclusion (Hodgson and Spours 1999a). A discrete qualification was designed to be part of the National Qualifications Framework, but at three levels of difficulty not just Level 3. As a result, the focus on accrediting the main three key skills within the new Key Skills Qualification effectively played down the importance of the Wider Key Skills. From the start, the Qualification thus risked being associated with a basic skills agenda and remediation rather than with advanced level skills for further study or skills for the future. Moreover, in an attempt to ensure credibility and status for the new Qualification, particularly in the eyes of employers, the Government opted for a strong external testing regime and a demanding portfolio approach. This has, as we shall see, created problems for embedding the key skills within learning programmes and for authentic assessment in the workplace.

Finally, the Government also opted for a voluntarist approach to the whole Curriculum 2000 agenda with regards to choices made by students and recognition by end-user such as universities. At the same time, in April 2000, colleges were offered funding incentives directly tied to the different elements of Curriculum 2000. With this came the attendant risk of the Key Skills Qualification being seen as 'semi-compulsory' - something which is not necessarily valued but which institutions impose on students.

This historical analysis suggests that the Government's approach to core/key skills within the Curriculum 2000 agenda was likely to be fundamentally flawed in these three respects - the emphasis on remediation skills and a deficit agenda, the role of assessment in the search for credibility and the issue of student and external recognition in a voluntarist system. How these factors would be played out in practice has to be seen in the context of the whole Curriculum 2000 reform process and its increased demands on students and institutions. 
THE KEY SKILLS QUALIFICATION IN THE CONTEXT OF CURRICULUM 2000

\section{The partial up-take of key skills - a step to universal participation?}

National surveys on Curriculum 2000 undertaken during 1999 and 2000 suggest that there is a high level of support amongst schools and colleges for offering opportunities to achieve key skills in the post-14 curriculum. However, they also suggest that there is much lower support for offering the Key Skills Qualification to the majority of their students. The Department for Education and Employment (DfEE) and Universities and Colleges Admissions' Service (UCAS) surveys undertaken in the Autumn of 1999 indicated that about $80 \%$ of schools and colleges intended to offer some form of key skills provision under Curriculum 2000 (DfEE/IOE 2000, UCAS 2000). At the same time, however, they also suggested a lower level of commitment to offering accreditation, with $60 \%$ intending to offer opportunities to achieve key skill units and as few as $22 \%$ offering opportunities for most students to achieve the full Key Skills Qualification. A more recent UCAS survey suggests a higher level of institutional involvement but still involving a minority of providers (UCAS 2001). This statistical picture, which suggests that involvement in key skills will be, at best, partial is still a matter of speculation and will only be confirmed at the end of 2002 when students have been offered a full two years to achieve accreditation.

The partial uptake of the Key Skills Qualification in the first year of implementation can be illuminated by the responses from different types of institutions. The IOE/Nuffield telephone snapshot survey of its 50 case-study institutions (see Appendix 1) in October 2000 suggested that for general further education colleges and sixth form colleges there would be a very high registration rate for the Key Skills Qualification, principally as a result of funding. On the other hand, there was negligible interest from independent and selective schools, with not one of the eight schools of this type in the 50 sample indicating any engagement with the qualification. Maintained 11-18 comprehensives lay somewhere between these poles with some responding in the same way as colleges (albeit without the funding incentives) and others hanging back to see what might happen (Savory et al. 2001). This institutionally variable approach was also confirmed by the UCAS survey undertaken in 2000 (UCAS 2001), though the latter showed a small degree of engagement by selective and independent schools. The Key Skills Qualification, 
which was intended for all advanced level learners, thus started its period of implementation with support from those institutions which catered predominantly for the average to below average advanced level learners. The institutions containing the highest achieving students, by and large, remained aloof.

Within this pattern of partial uptake, four other trends emerged during 2000/1. The first was a progressive decline of student participation within key skills provision as the year proceeded. Some colleges reported that they had all the provision in place but with a minority of students involved and low numbers turning up for tests. In other institutions within our 50-site sample, students themselves reported that a relatively small number of their peers persevered with key skills lessons. The second noticeable trend was poor early test results, particularly at Level 3 Application of Number, with a small minority of students passing and very high failure rates in other Level 3 units. The third trend, and related to the second, is what might be termed 'a retreat from Level 3'. Many schools and colleges originally anticipated that their students would be registered for Level 3. However, in the light of their experience in the final term or two and seeing the early tests, they decided to enter advanced level students at Level 2, in particular in Application of Number (Hodgson et al. 2001). Finally, despite apparent widespread support in principle for the Wider Key Skills, there has been a very low uptake of these with only three to seven per cent of students taking any of these units (UCAS 2001).

These actions throughout the first year of implementation of the Key Skills Qualification, which was supposedly designed for all, can be interpreted as 'retreating' on a number of fronts. The effect has been to introduce further caution about introducing the Key Skills Qualification and has led to questioning of participation and a call for realism. Colleges appear to be working mainly at Level 2 rather than Level 3. Some institutions, particularly schools, will reduce the number of students being entered for the Qualification and will focus on achieving one or more units. Some schools which might have come on board in September 2001 will continue to hold back and some will press on to use the second year of study to try to achieve the qualification. Although this participation picture is a rough snapshot of a moving position, what has become clear, is that the Key Skills Qualification has not reached a position of 'take-off' after its first year of implementation. 


\section{Key skills in context - the demands of Curriculum 2000 and issues of recognition}

The student response to the Key Skills Qualification in the first year of implementation has possibly been the most decisive factor working against its success. Virtually all the practitioners we interviewed during 1999/2000 as part of the IOE/Nuffield Research Project foresaw difficulties with convincing students to take the Key Skills Qualification, but no-one really anticipated the scale and intensity of student resistance and the support they would receive from their parents. This comment from one school head of sixth serves to illustrate what is a very widespread problem:

'we had one classic conversation with parents of a very gifted, very able student, he said, if you make him do key skills then I don't want him coming into your sixth form'.

The Key Skills Qualification is overwhelmingly viewed by students and by practitioners as a 'hassle' and without much 'currency' with little 'use' or 'exchange' value. Indeed, it is interesting to note that in every interview we have had with students as part of our visits to the 50 sites in the IOE/Nuffield Project, when we have asked them what they are studying, none of them has mentioned key skills. When we go on to ask whether they are following a key skill programme or are aware of key skills, they burst out laughing. It is at this point that students invariably use words like 'pointless", "a waste of time' and other less polite phrases!

Student resistance to the Key Skills Qualification is exacerbated by its relationship with the other components of Curriculum 2000. Research from our most recent site visits suggests that the teacher and student experience of the AS qualification - rushed, overloaded with content and often taught to the full A Level standard - has particularly served to marginalise key skills. Factors internal to Curriculum 2000 - the concept of choice, more subjects and increased workloads - meant it was inevitable that students would prioritise what was important to them and the Key Skills Qualification clearly was not.

A major negative factor for advanced level students and teachers is the attitude of universities. The message about the Key Skills Qualification that has gradually seeped out from higher education is one of 'stand-off' and senior managers in schools and colleges have been only too aware of the potential consequences of universities not providing clear incentives to recognise it. The following remark from a senior manager reflected widely-held apprehensions. 
'Key skills will be dead in the water unless universities recognise them, including selecting universities, which I have a fear they won't do'.

There are several reasons for the current 'stand-off'. First, the Key Skills Qualification is an unknown entity and it is highly likely that admissions tutors will take the same view as many schools in seeing the qualification as 'remedial' and associated with basic skills. Second, the preferred position of many universities is to require particular A Level grades and this position has not changed radically as a result of Curriculum 2000 despite the publication of the pointsbased UCAS Tariff for admission to higher education. Third, and probably most importantly, is a fear of requiring a qualification that will not be universally taken by their pool of applicants. In the case of this last factor, both 'selector' and 'recruiter' universities, would need to see a dramatic uptake of the Key Skills Qualification in all types of 16-19 institutions in order to feel safe in coming off the fence and asking for the Key Skills Qualification as part of their admissions requirements.

\section{Purpose - the wrong key skills emphasis?}

The focus of key skills development in the Key Skills Qualification is the result of two related policy trends. First, Dearing's assumption that the main role of key skills is to promote employability - hence the three key skills of Communication, Application of Number and IT rather than the broader six core skills (Dearing 1996). Second, these three key skills were chosen because there was an assumption of skills deficits in these areas. This focus of the Key Skills Qualification has contributed to the image amongst students and many teachers that key skills is about something which should have been achieved in secondary education. Some students have gone as far as labelling the Qualification 'insulting'. The reminder of repetition of learning is also brought home by the use of the 'proxies' of $\mathrm{A}^{*}-\mathrm{C}$ General Certification of Secondary Education (GCSE) grades in maths and English as substitutes for the external tests in Application of Number and Communication. Students we have interviewed overwhelmingly reject the Key Skills Qualification on the grounds that they have 'done this before' and that it has little 'usevalue' or 'exchange value'. In our experience, the most sceptical are students who intend to progress to higher education. Some of those who aim to go straight to employment are slightly less negative about the three main key skills because they assume that these are the skills 
employers want, although recent research suggests that this may not, in fact, be the case (Henry 2001).

\section{Assessment-led problems - the cumulative effects of tests and the portfolio}

Virtually every practitioner we have talked to over the past two years as part of the IOE/Nuffield Research Project has remarked on the problems of assessing key skills. This is a long-standing issue, as the historical account earlier in this paper has already highlighted, but one which has become acute with the design of the Key Skills Qualification.

An awareness of this problem was already emerging during 1999. Mindful of the key skills pilots and the experience of GNVQs, practitioners pointed to the looming complexity of the assessment regime arising from mapping key skill opportunities across different A Level and vocational subjects; to the potential pitfalls of the tests and to the inevitable bureaucracy of recording associated with the portfolio. In the 1999/2000 DfEE survey of Curriculum 2000, implementing key skills was identified by practitioners as the main practical problem looming for schools and colleges (DfEE/IOE 2000).

Units of the Key Skills Qualification are assessed by both portfolio and by tests. What practitioners say is that it is the cumulative effect of these two approaches which leads to problems of complexity, bureaucracy and non-achievement. Initial signs are that the key skills tests are proving to be too difficult for many students who would benefit from skills development but who risk being demotivated to complete the Key Skills Qualification. The tests are assessed on a pass/fail basis with a $70 \%$ mastery threshold which tends not to recognise partial achievement. In the case of Level 3 tests, the questions range from being relatively accessible at the beginning of the paper to extremely difficult at the end. The compilation of the portfolio is also seen as a major assessment hurdle due to the increasing complexity of assessment criteria.

Key skills development has been analysed historically throughout the 1990s by researchers from the University of Nottingham. Their research suggests that the development of a more 'regulatory' and qualifications approach to key skills has encouraged mechanical forms of learning in which satisfying assessment criteria has tended to override objectives related to longterm personal development (Murphy and Wilmut 2000). 
The overall effect of these changes to the assessment requirements for key skills has been to make the favoured 'embedded' delivery method (that is the delivery of key skills through students'main chosen subjects) more difficult, if not impossible to put into practice.

An assessment-led approach to taking evidence from subjects also fails to inspire. Students comment on the meaningless drudgery of putting together their portfolios for the Key Skills Qualification. The transfer of written work from a subject file to a key skills file has been labelled as 'pointless', particularly in the context of more subjects to study. For those institutions involved, the effects have been noticeable with the assessment demands triggering a new level of student disaffection mid-way through the programme and more heart-searching amongst dedicated key skills staff who are having to deal with growing disenchantment amongst their colleagues.

The process of growing disillusionment with the assessment requirements of the Key Skills Qualification as the year progressed was summed up for us by a single moment of defeat for a 'key skills champion' in one of our 50 sample sites. A Head of Sixth, keen to promote key skills, sent home a letter to some parents reminding them that their child was not up to date with her/his portfolio. He received a number of abusive letters and telephone calls in response and, as a result of the level of student resistance and lack of parental support, he decided he was not able to go on. He has since taken up a job in a sixth form that does not deliver the Key Skills Qualification.

\section{'TWEAKING' OR 'REFORMING' THE KEY SKILLS QUALIFICATION: OPTIONS FOR THE POLICY PROCESS}

The first year of the Key Skills Qualification has been one of initial professional commitment to key skills development, but also one of problems far greater than anticipated. While official evaluations report evidence of islands of good practice amidst general difficulties of implementation and recognition (LSDA 2001, CEI 2001) students have resisted the reform on an unprecedented scale and key skill development has not made headway into subject areas. By the end of its first year of implementation, the position of the Key Skills Qualification had reached a point where headteachers were threatening to boycott it in 2001/2002 (Woodward 2001). It is our assessment that the Key Skills Qualification is not poised for 'take-off' with all advanced level students. Rather, it is becoming ghettoised as a qualification for further education colleges and 
lower achieving students, echoing the fate of earlier key skill developments. The Qualification cannot now simply be described as having 'teething problems': our analysis suggests it is suffering from more fundamental issues related to its context, purpose and design.

First, while the Government would like all 16-19 year old learners to develop key skills as part of their advanced level study programmes, there is little incentive for them to do so. The Qualification is not part of an overarching certificate framework, it is complex and arduous to achieve and appears to be worth very little in the eyes of higher education institutions. And while the views of employers have not yet been fully established, there are early indications that the three main key skills are not what they are most interested in (Unwin et al. 2000, Henry 2001). As one commentator remarked 'The qualification has a high hassle factor and a low exchange value'. More importantly, the majority of the first cohort of advanced level students to experience the Curriculum 2000 reforms, is struggling to cope with four or more AS/AVCE subjects. As we have pointed out earlier, this is not the context in which to introduce a new and potentially under-valued additional qualification.

Second, the development of a Key Skills Qualification in Communication, Application of Number and IT associates it with basic skills and remediation rather than with advanced level skills and skills for the future (Young 2001). This is particularly unfortunate in the context of Curriculum 2000 which is intended to be about advanced level programmes for 16-19 year olds. In learners' minds, as we have seen from the empirical research described earlier in the paper, the Qualification is associated with the past and looking back to learning that has already been undertaken, rather than looking to the future and developing the new skills required for progression to further study or the workplace.

Third, in its current form the Key Skills Qualification is driven by assessment rather than by curriculum or learning principles. Both the requirements of the portfolio element of the assessment and the external tests make an embedding approach to the delivery of the qualification very difficult. Teaching to the test appears to be necessary in order to ensure any measure of success, particularly in relation to Application of Number. Moreover, the exhaustive evidence gathering required to satisfy the assessment criteria for the Qualification leads to a paper-chase rather than to the development of new skills.

Until June 2001 and the announcement by the new Secretary of State, Estelle Morris, of a review of Curriculum 2000 led by Professor David Hargreaves, Head of the Qualifications and 
Curriculum Authority (QCA), it was possible to locate two different but not necessarily mutually exclusive positions on what needed to be done to tackle the problems that had emerged with the Key Skills Qualification in its first year of implementation.

The first position, which was to be found in the majority of the official evaluations of the Key Skills Qualification, acknowledged that there were implementation problems, but suggested that these could be dealt with by focusing on lessons emerging from examples of institutional best practice in this area and raising awareness of the Qualification. Those who took this view believed that it was important for the reform process to be given more time to 'bed in' and, while minor changes to aspects of the Qualification might need to be made, for example reviewing some of the test papers in Application of Number, there was no urgency to consider a more fundamental review of the Key Skills Qualification's role, purpose or design or the Government's current key skill strategy in relation to Curriculum 2000. This could be termed a 'tweaking approach'.

The second position, to which we subscribe, examines the Key Skills Qualification in its wider context and identifies more deep-seated problems of purpose and design in relation to full-time study at advanced level. Those who hold this view start from a historical and policy analysis which suggests that the type of problems the Key Skills Qualification currently faces are not new and are unlikely to go away unless the Government takes a different approach to its key skills strategy in the future. Such an analysis leads to arguments for a more fundamental review of the Key Skills Qualification within an overall consideration of the Curriculum 2000 reforms and 1419 education and training in general in order to increase the 'use value' and 'exchange value' of key skills as a whole.

This 'reform approach' would involve shifting the emphasis away from assessing key skills for a national qualification towards using a broader range of key skills for teaching and learning development. This would mean creating a sharper distinction between basic skills and advanced level key skills than is currently the case and, in doing so, confining the Key Skills Qualification to Level 2 and below and at advanced level focusing more on achievement of the wider key skills units and others types of skills which may be developed in the future. This shift in emphasis would be more likely to make key skills attractive to higher education providers and employers. 
It will also be important to give learners a choice of key skills units so that they can focus on those most appropriate to their progression destination. Our interviews with Year 12 students suggest that their principal reason for supporting Curriculum 2000 is the increased choice and flexibility it provides. Key skills, on the other hand, currently have an air of 'semi-compulsion' which makes them particularly unattractive in the context of increased workloads under Curriculum 2000. The idea of compulsion has been exacerbated by creating funding incentives for colleges to offer the Key Skills Qualification when learners have little incentive to achieve them. Any changes that are made to key skills will have to increase the sense of personal ownership, use and exchange value for learners themselves as part of creating a balance of incentives for all parties involved in key skills development.

During our research, both students and teachers have repeatedly stated that they want key skills to aid teaching, learning and achievement at advanced level. Moreover, they have bemoaned the decline of enrichment activity under Curriculum 2000. A shift of emphasis to the wider key skills and areas like Critical Thinking will help to address these issues. However, the major barrier to this move is the current assessment regime within the Key Skills Qualification. What is needed is the realisation that a free-standing qualification is not what is required at advanced level. Taking key skills out of the National Qualifications Framework and its external assessment demands would allow a 'fitness for purpose' assessment approach that would encourage their development within subjects, workplace settings and enrichment activities.

Finally, it has to be noted that the revolt against the Key Skills Qualification has taken place within the context of a complicated and arduous Curriculum 2000 framework. In the longer term the development of skills for improved learning and for working life have to be seen in the broader context of a coherent and inclusive 14+ curriculum and qualifications framework. Such a framework would allow for the progressive development of skills over time and avoid the need for an additional and over-assessed Key Skills Qualification based on remediating for deficits. We see the shift in emphasis towards the wider and more progression-oriented key skills at advanced level, outlined above, as a necessary first step in this direction. 
The Hargreaves Review of Curriculum 2000 (Hargreaves 2001) has basically supported the 'reform' rather than the 'tweaking' position on key skills. However, the Government response to the Hargreaves Review (DfES 2001) takes a less radical position in relation to the Key Skills Qualification. Ministers have, so far, decided to allow more choice for students and to reduce the assessment burden in the current Key Skills Qualification but do not recognise the importance of developing the wider key skills. To date, the Government has signalled a retreat from an untenable position in relation to the Key Skills Qualification, but we would argue that it has not yet developed a strategy which effectively lays the basis of key skills for all.

\section{NOTES ON KEY TERMS IN ORDER OF THEIR APPEARANCE IN THE TEXT}

Key Skills Qualification is a qualification in Communication, Application of Number and Information Technology available at different levels of difficulty which was introduced in September 2000.

The Curriculum 2000 reforms introduced in September 2000 aim to broaden programmes of study for advanced level students by introducing a new range of qualifications which can be combined in a flexible way. The reforms involve changes to A Levels (the introduction of Advanced Subsidiary Level and A2s which together make up an A Level); to GNVQs (their replacement by AVCEs) and the introduction of the new Key Skills Qualification and Advanced Extension Awards. It was expected that advanced level students would take up to five subjects in their first year of study compared with two to three under the old system. However, there is no compulsion on either schools, colleges or students to take a particular number, spread or combination of subjects. We refer to this as a voluntarist arrangement.

The English context - we have singled out England rather than the UK as the focus of this journal article because the key skills reform process and the qualifications reform process as a whole have historically been and still are different in Scotland, Wales and Northern Ireland.

UVP and YTS were training programmes aimed at unemployed 16 year olds during the late 1970s and early 1980s. CPVE was a curriculum and qualifications framework aimed at school-leavers 
who wished to stay in full-time education but wanted to undertake vocational education in a number of different settings.

TVEI was a government funding initiative introduced in the mid-1980s aimed at vocationalising the upper secondary curriculum and in its Extension Phase was experienced by all 14-19 year olds in full-time education in the UK.

$H M I$ was the national education inspectorate prior to the foundation of the Office for Standards in Education (Ofsted) in the 1990s.

$S E A C$ was one of a number of national bodies responsible for both monitoring qualifications and curriculum development in England during the 1980s.

NCVQ (National Council for Vocational Qualifications) established in 1986 was responsible for the development of National Vocational Qualifications (NVQs).

NCC, established in 1988, was responsible for the implementation of the National Curriculum in England, Wales and Northern Ireland.

$D E S, D f E$ and $D f E E$ are earlier names for the education ministry is now known as the $D f E S$ (Department for Education and Skills).

1991 White Paper - Education and Training for the $21^{\text {st }}$ Century - marked the establishment of a more explicitly track-based post-16 qualifications system in England, Wales and Northern Ireland which accentuated the divide between academic (A Levels), broad vocational education (GNVQs) and occupational training (NVQs).

GNVQs, introduced in 1992, were a broad vocational qualification at a number of levels initially designed to be offered to 16-19 year old students in full-time education.

SCAA was the result of the merger of NCC and SEAC into a single regulatory authority for academic qualifications and the National Curriculum. 
FEFC, established in 1993, was the national body with responsibility for funding and inspecting further education colleges in England, Wales and Northern Ireland. During the period 1993-2001 schools continued to be funded by local education authorities. From 2002, schools, colleges and work-based training providers will be funded by a single organisation - The Learning and Skills Council (LSC).

The Beaumont, Capey and Dearing Reports (1995-6) were the result of government-sponsored reviews into various types of post-16 qualifications. The Dearing Report (1996) was seen as the most influential and comprehensive of these, contained recommendations related to all three reviews and laid the basis for the reform process known as Curriculum 2000.

$S V Q s$ are the Scottish equivalent of NVQs.

Qualifying for Success (1997) was a consultation document issued by the incoming Labour Government which sought views on proposed changes to advanced level qualifications originally proposed in the Dearing Report under a Conservative Administration.

Level 3 is advanced level and one of six levels in the National Qualifications Framework which contains nationally-recognised post-14 qualifications from Entry Level through to post-graduate study.

Advanced Level National Certificate and Diploma awards were proposed in the Dearing Report (1996) as a way of developing a baccalaureate-type qualification at Intermediate and Advanced levels.

Key Skills Support Programme is a government-funded initiative aimed at supporting the introduction of the new Key Skills Qualification.

LSDA, which was set up at the same time as the Learning and Skills Council, is a governmentfunded body which advises the Government on post-16 policy developments and provides guidance and support for all post-16 providers with the exception of higher education institutions. 
Curriculum 2000 entitlement programmes refer to funded programmes of study in further education colleges which include key skills, guidance, tutorials and enrichment or extra-curricular activities.

$U C A S$ is the independent body responsible for administering admissions to higher education institutions in the UK. The UCAS Tariff is a system of allocating points to the different types of qualifications applicants for university places offer for admission to higher education.

GCSE is the main set of examinations taken at 16 years at the end of compulsory education. Students take up to 10 subjects which are graded from $A^{*}$ to $G$, but four to five $A^{*}$-C grades at GCSE provide access to Advanced Level study.

$Q C A$ is the merged curriculum and qualifications regulatory body which superseded both SCAA and NCVQ in the mid 1990s. 


\section{APPENDIX 1}

\section{The Institute of Education/Nuffield Foundation Research Project Broadening the Advanced Level Curriculum: Institutional Responses to the 'Qualifying for Success' Reforms}

Following the Qualifying for Success (QfS) consultation process in 1997, the Government announced qualifications reforms to broaden the advanced level curriculum. The Institute of Education (IoE)/Nuffield Foundation Project examines how schools and colleges are responding to the reforms which were introduced in September 2000.

The Project employs three inter-related approaches to researching the role of institutions in these qualifications reforms:

- desk research and interviews with key national agencies were used to identify emerging issues as schools and colleges planned for the reforms during 1999/2000, and again to examine how the reforms evolved throughout the academic year 2000/2001;

- data from a number of national surveys on Curriculum 2000 have been analysed to provide a quantitative picture of institutions' advanced level curriculum provision before and after the introduction of the qualifications changes as well as changes in students' programmes of study;

- further qualitative data has been collected from 50 schools and colleges across England in order to examine in more detail changes to the advanced level curriculum offer in these institutions, how student study programmes have been affected by the reforms and what major factors have affected both institutional and student decision-making. These data have been collected through two sets of site visits during the academic years 1999/2000 and 2000/2001. Each visit involved interviews and discussions with a number of key actors within the institution. During the first set of site visits, headteachers of schools or principals of colleges were interviewed to obtain an overview of the institution's response to Curriculum 2000. In addition, lengthier discussions took place with deputy heads/viceprincipals/curriculum directors or heads of sixth form around the detail of their Curriculum 2000 provision and implementation issues. In schools, Year 11 students were interviewed to 
gain their views on the prospect of undertaking an expanded advanced level curriculum. In the case of general further education colleges and sixth form colleges, heads of department or faculties were questioned to find out their views on the effects of the Curriculum 2000 on their subject areas. All the interviews were taped and transcribed before being analysed. During the second set of site visits, carried out in the Spring and Summer Terms 2001, slightly different key players were interviewed in order to focus more specifically on student programmes of study and to capture the student experience of Curriculum 2000.

The 50 institutions chosen for site visits represented a theoretical sample of schools and colleges. The sample was designed to reflect and exemplify the following characteristics which earlier work suggested were important in determining institutional responses to qualifications and curriculum reform (Hodgson and Spours 1999a, 1999b and 2000).

\section{Type of institution}

All institutional types offering advanced level provision to 16-19 year olds are represented in the sample - 11-18 comprehensive schools; selective schools; independent schools; sixth form colleges; and general further education colleges.

\section{Size of sixth form}

The 11-18 school sixth forms were chosen according to numbers of students and thus represent a spectrum from 30 to 630 .

\section{Curriculum offer}

The schools were also chosen according to their advanced level provision prior to Curriculum 2000; they thus range from sixth forms which offered only A Levels through to those with more than $50 \%$ GNVQ provision.

\section{Geographical spread}

Institutions are located in different parts of the country - the North West, the North East, the East Midlands, East Anglia, London, the Home Counties and the South West. 
Locality

It was felt that institutions serving different localities might have different responses to Curriculum 2000. The sample thus includes schools and colleges in inner city, urban, suburban, provincial and rural settings.

Competitive/non-competitive environment

Previous research had suggested that the level of competition among providers might make a difference to their response to Curriculum 2000. The sample of 50 schools and colleges therefore includes some institutions in highly competitive environments as well as those in non-competitive environments, with some schools involved in formal co-operation.

By using these criteria for selecting our sample we have also achieved a wide spread of student intake in terms of average GCSE scores, average A level scores, and percentage of the cohort progressing onto higher education. We were also careful not to approach any of the schools and colleges involved in either QCA or FEDA projects on Curriculum 2000 to avoid overburdening these institutions. 


\section{REFERENCES}

Association of Principals of Sixth Form Colleges (APVIC) (1991) A Framework for Growth: Improving the Post-16 Curriculum (Wigan: APVIC)

Beaumont, G. (1995) Review of 100 NVQs and SVQs. (London: DfEE)

Bullock, A. (1975) A Language for Life: Report of The Committee of Inquiry into English Language Teaching (London: HMSO)

Callaghan, J, (1976) Ruskin College Speech The Times Educational Supplement 22nd

October

Capey, J. (1996) GNVQ Assessment Review (London: NCVQ)

Centre for Education and Industry (CEI) 2001 Independent Reassert to Evaluate the Introduction of the Key Skills Qualification: Final Report, Centre for Education and Industry, University of Warwick

Cockcroft, W. (1982) Mathematics Counts: Report of the Committee of Inquiry into the Teaching of Mathematics in Schools (London: HMSO)

Confederation of British Industry (CBI) (1989) Towards a Skills Revolution: Report of the Vocational Education and Training Task Force (London: CBI)

Dearing, R. (1996) Review of Qualifications for 16-19 Year Olds (London: SCAA)

Department for Education and Science (DES) (1985) International Statistical Comparisons of the Education and Training for 16-18 Year Olds (London: HMSO)

Department for Education (DfE), Employment Department (ED), Welsh Office (WO) (1991) Education and Training for the 21st Century (London: HMSO)

Department for Education and Employment (DfEE)/Department of Education Northern Ireland (DENI)/Welsh Office (WO) (1997) Qualifying for Success: A Consultation Paper on the Future of Post-16 Qualifications (London: Crown Copyright)

DfEE/IoE (2000) Qualifying for Success Reforms. unpublished report.

DfES (2001) Government Response to QCA Report (London: DfES)

Department of Employment (DE) (1988) Employment for the 1990s (London: HMSO)

Department of Employment (DE) (1989) Training in Britain (London: HMSO)

Finegold, D. Keep, E., Miliband, D. Raffe, D., Spours, K. \& Young, M. (1990) A British Baccalaureate: Overcoming Divisions Between Education and Training (London: IPPR)

Further Education Funding Council (FEFC) (1994) General National Vocational Qualifications in the Further education Sector in England (Coventry: FEFC)

Further Education Unit (FEU) (1979) A Basis for Choice (London: FEU) 
Green, A. (1997) Core Skills, General Education and Unification in Post-16 Education, in Hodgson, A. \& Spours, K. (eds) Dearing and Beyond: 14-19 Qualifications, Frameworks and Systems (London: Kogan Page)

Hargreaves, D. (2001) Review of Curriculum 2000 - QCA's Report on Phase One (London: QCA) Henry, J. (2001) Schools hit the wrong key skills Times Education Supplement 25 May

Her Majesty's Inspectorate (HMI) (1989 Post-16 Education and Training, Core Skills: An HMI Paper (London: HMSO)

HMI (1996) Assessment of General Vocational Qualifications in Schools 1995-96 (London: HMSO)

Hodgson, A. and Spours, K. (1997) From the 1991 White Paper to the Dearing Report: A Conceptual and Historical Framework for the 1990s, in Hodgson, A. \& Spours, K. (eds) Dearing and Beyond: 14-19 Qualifications, Frameworks and Systems (London: Kogan Page)

Hodgson, A. and Spours, K. (1999a) New Labour's Educational Agenda: Issues and Policies for Education and Training from 14+ (London: Kogan Page)

Hodgson, A. and Spours, K. (1999b) Planning for the New 16-19 Qualifications Era. An Institute of Education and Essex LEA Research and Development Project. Essex LEA/Institute of Education, University of London

Hodgson, A. and Spours, K. (2000) Qualifying for Success: Towards a Framework of Understanding, Broadening the Advanced Level Curriculum IOE/Nuffield Series No. 1, Lifelong Learning Group. Institute of Education, University of London

Hodgson, A. Spours, K. and Savory, C. (2001) Improving the 'Use' and 'Exchange' Value of Key Skills: Debating the Role of the Key Skills Qualification Within Curriculum 2000, Broadening the Advanced Level Curriculum IOE/Nuffield Series No. 4, Lifelong Learning Group. Institute of Education, University of London

Institute of Directors (IOD) (1992) Performance and Potential: Education and Training for a Market Economy (London: IOD)

Learning and Skills Development Agency (LSDA) (2001) Response to QCA from the Key Skills Support Programme (London: LSDA)

Murphy, R. \& Wilmut, J. (2001) Evaluating the Development and Introduction of the Key Skills Qualification. Unpublished paper presented at DfEE Researchers' Forum, Spring 2001

National Council for Vocational Qualifications (NCVQ) (1991) General National Vocational Qualification: Proposals (London: NCVQ)

National Curriculum Council (NCC) (1990) Core Skills 16-19 (York: NCC)

Oates, T. (1992) Developing and Piloting the NCVQ Core Skill Units (London: NCVQ) 
Oates, T. (1996) The Development and Implementation of Key Skills in England (London: NCVQ)

Organisation for Economic Co-operation and Development (OECD) (1985) Education and Training after Basic Schooling (Paris: OECD)

Qualifications and Curriculum Authority (QCA) (1999) Qualifications 16-19: A Guide to the Changes Resulting From the 'Qualifying for Success' Consultation (London: QCA)

Raffe, D., Howieson, C., Spours, K. and Young, M. (1998) The unification of post-compulsory education: Towards a conceptual framework British Journal of Educational Studies. 46 (2), 169187

Royal Society (1991) Beyond GCSE (London: Royal Society)

Savory, C., Hodgson, A., and Spours, K. (2001) Planning and Implementing Curriculum 2000: Institutional Approaches, Broadening the Advanced Level Curriculum, IOE/Nuffield Series No. 3, Institute of Education, University of London.

School Examinations and Assessment Council (SEAC) (1991) Core Skills and A/AS Examinations: Report by the School Examinations and Assessment Council on the 1991 Exemplification Exercise (London: SEAC)

Secondary Heads' Association (SHA) (1993) 14-19 Pathways to Achievement: A Discussion Paper (Leicester: SHA)

Unwin, L., Wellington, J., Fuller, A. and Cole, P. (2000) Effective Delivery of Key Skills in Schools, Colleges and Workplaces, Centre for Research in Post-Compulsory Education and Training, University of Sheffield (Sheffield: DfEE) Universities' and Colleges' Admissions Service (UCAS) (2000) Post-16 Provision in Schools and Colleges 2000-2001: Final Report on and Analysis of Curriculum 2000 (Cheltenham: UCAS) UCAS (2001) Report on Survey of provision and Take-up of Curriculum 2000 in Schools and colleges - November 2000 (Cheltenham: UCAS)

Woodward, W. (2001) New exams for sixth formers condemned as shambolic The Guardian 31 May

Young, M. (2001) Key Skills and the Post-Compulsory Curriculum. Paper delivered at the Key Skills for All? Conference, Institute of Education, University of London, 17 May 